\title{
Technological Development \& Globalisation: The Importance of Incubators and Science Parks for the Generation of New Interprises
}

\section{Dr William K Bolton}

Director of Research and Development

The David Hall Partnership Lid.

\section{The Setting}

For many of us it is self-evident that business incubators and science parks are important for the generation of new enterprises. Some, myself included, would go further. We would say that they are an essential part of the infrastructure that is required to support the process of enterprise generation and growth. In this paper I will describe this process and the key role which can be played by incubators and science parks.

First however I would like to comment on those who do not share these views. They are in two groups. Firstly there are those who see incubators and science parks mainly, and sometimes only, in terms of property development and a commercial opportunity. The second group includes those who consider that the generation of new enterprises is something that happens spontancously and which cannot be planmed. For this reason they consider that incubators and science parks are an Belo Horizonte, Vol 6, N², p.213-224 expensive luxury and make very little difference to the situation.

\subsection{The Property Development View}

The property development view rests upon the necessity for any project which involves land and buildings to be financially viable. It is sidly true that there are many cases where enthusiasm for the concept has overridden these important commercial considerations with the result that a financial rescue has to be mounted. Such action generally results in a redirection of the project away from its original aims or simply the sale of the assels.

With these concerns in mind it is relevant to note that the definition of a science park used by the UK Science Parks Association begins with the statement that a science park is a property-based initialive.

The Docklands Enterprise Centre in East London provides an interesting example of what happens when the

Dez.1996 


\section{PRODUÇÃO}

property development view prevails. This fairly large business incubator (it has 46 units) was opened about 8 years ago. After struggling to achieve viability for several years it finally altracted support from a major bank which seconded one of its staff to be the Centre Director. With this support the project achieved success and the local newspaper carried the headline 'House Full at Enterprise Centre'.

In the last year the siluation has completely changed and the Enterprise Centre is no longer an incubator. The building is run by a property group whose aim is to maximise the rental incone for its owner. This change came about when the building was sold and the new owner wanted to maximise the return on his investment and was not interested in helping early-slage businesses. However the necd for an incubator in the area has not changed and the Centre Manager still has three busincsses a week making enquiries about start-up units and she has to turn them away.

In this example we see lwo major reasons for the commercial failure of incubators and science parks. One is when direct or indirect subsidy of the project is withdrawn and it becomes no longer financially viable. The second is when the ownership changes. often because of financial problems. and the new owner is not interested in the original concept and turns it into a property investment project.

\subsection{The Business Generation View}

This view questions the use of business incubators and science parks as new enterprise genemotors. It notes that the spontaneous generation of technologybased businesses has taken place withoul the help of business incubators and quoles as cxamples Silicon Valley. California, Roule 128, Boston and Cambridge, England.

Il also notes that spontilleous enterprise generation has not laken place in large science parks like Sophia Antipolis, in France, the Research Triangle in North Carolina, USA and Tsukuba, Science City near Tokyo.

On this evidence it is concluded that incubators and science parks are not important for the generation of new cnterprises. This is a false conclusion because it confuses the process with its support struclures. Allhough a support structure provides the cuvironment in which the process can flourish, without the process nothing will happen. The reason that the larger science parks mentioned above have not experienced the spontaneous growlh of new enterprises is that the process of new cnterprise generation is not well developed on these parks.

The emergence of a spontaneous selfgencrating process of enterprise generation as in Silicon Valley: without the presence of incubators makes cxactly the same point. The process is what matlers and if it is strong cnough in a region then it will overcome the lack of support facilitics. This however is not an argument against incubators and science parks because there is no doubt that they can play an important role in stimulating the enterprise generation process. I was 


\section{PRODUÇÃO}

interested to be told on a visit to Stanford Researcl Park a few years ago that if they began the Park again they would start with a business incubaltor. This is an important comment from the world's first and most successful science park.

The requirement then is twofold.

i) To develop the process of new enterprise generation

ii) To provide facilities, such as incubattors and science parks, to support that process.

Subsequent sections of this paper deal with these two issues.

\section{The New Enterprise Generation Process}

Three steps can be identified in the new enterprise generation process. They are:

Step I - Evaluating the extent to which the process is already lappening

Step 2 - Building the new enterprise generation process

Step 3 - Developing and conlinning the process to rcach a critical mass

Step 1 - Evaluating the extent to which the process is already happening.

The generation of new enterprises is a natural process and in my experience is already taking place in our universities and in our communities. The difficulty is that it is nol always recognised and there are many barriers which stifle the process. For example a light university policy on intellectual policy will deter entrepreneurial activily in the university.

In visits 10 universities in Latin Americal as part of the CRE - Columbus Incubator project I was often told that there had been no spin-off enterprises from the university. Yet in almost every case further questioning revealed that there had been spintoffs and that the process of enterprise generation was taking place but at a low level. Similarly in a recent sludy by the David Hall Partmership in the Highlands and Islands of Scotland, which is a relatively remole rural area, we were told that there was little indigenous business activity and yet in a survey we found almosi 50 enterprises at various stages of start-ıp.

Valuable experience can be gained by working with what is already happening and bringing it to fruition. In general however this will not be sulficient to reach a self-generating siluation and some form of new enterprise generation mechanism has to be put in place to increase the flow and quality of new enterprises.

\section{Step 2 - Building the process.}

A number of mechanisms has been developed for the generation of new enterprises and some have a specific university focus but essentially they all have the same inputs in some form. These are : 
- People

- Business Opportunities

- Finance

Each is a major topic in itself but briefly the generation of an enterprise is started by one or two key people who see a particular business opportunity. For the UK, studies have shown that $10 \%$ to $15 \%$ of the population has at some time considered selting up their own business. In my work with students studying industrial engineering at Cambridge University I ran a 'new enterprise' projecl and found the same percentage of potential entrepreneurs.

Students are an important entrepreneurial resource and the university sector call play an key role in identifying potential entreprenieurs amongst its students and then providing them with business training and help to identify and evaluate a business opportunity. Some form of Entrepreneur School is an effective way to meet this 'people' requirement.

The university can also help to identify business opportunities through their research programmes and their work with industry. This can be an important addition to the role of a university industrial liaison office or a technology transfer unit.

The process of bringing people and business opportunities together to form an enterprise can either be left to lake place naturally or else mechanisms can be put in place to generate the new enterprises. In practice some form of intervention will almost certainly be needed to generate the required stream of new enterprises.

An intervention programme has been developed by The David Hall Partnership under the title 'Enterprise Cells'. This programme puts people together into enterprise teams and then introduces them to a business opportunity. The team evaluates its business opportunity and then goes forward to prepare a business plan, obtain funding and launch the business.

Finance is a more difficult issue because new enterprises are perceived as high risk and difficult for the fund provider 10 manage. In reality this need not be the case. I have been associated with a seed capilal fund for some years which provides finance to support the commercial devclopment of promising research work in the University of Cambridge. After a slow start this fund now has a portfolio of investments valued at around $\$ 5$ million for a cash investment of $\$ 2$ million.

Step 3 - Developing and continuing the process to reach a critical mass.

Here it is important to recognise that as new enterprises develop they pass lhrough a series of growth stages. In a model that has been tested in a number of applications five growth stages are defined, mamely:

Embryo Stage - the product moves from a demonstration unit to a fully working protolype which can be shown to potential clients 
Nurture Slage - llic producl moves on to the point where it can be sold and the business begins to trade

Fledgling Slage - the business develops and moves into profit, the market cxpands and the company offers a range of products

Maluring Stage - the business grows to a size that is operationally viable and it achicves an established position in the market place

Business Stage - this stage is gencrally a sequence of consolidation and expansion plases

Although these stages show a lincar sequence. in praclice the first three slages. which are more product-rclated, can be laking place within the Maturing and Business Stages. However even in this siluation the presence of these early stages Imust be recognised and mamaged if new products are 10 achicve their market potential within an existing organisation.

11 is imporlant 10 cusurc lhat businesses move through these stages steadily so that willin a region a regular now of new enterprises is generated which in duc course build a critical mass or business cluster and the process becomes sclf-gcucraling.

In some regions it is helpful to have a stralcgic focus upon onc or lwo key seclors. For cxample in a project in linverness. Scolland the sectors of heallhcare and iclecommunications have been identified as their priority arcas. Their strategy is to ellcourage both illward investment and new enterprise generalion iil linese sectors.

\section{Supporting the Enterprise Process}

The culcrprise process, from idea to mature business, has to operate within the realities of its environment. In many regions this environment is hostile to the cutcrprise process and llicre are barricrs which slow down the cnterprise process and prevent it from developing. In olher regions the enviromment is not adverse but lhere are key elements of the infrast ructure not in place. For example financial support for new culerprises may nol be available. These faclors have a direct result upon the health of the new enterprise process and upon the number of culerprises that are required before the process becomes self-sustaining.

In considering this coviromment it is helpful to distinguish belween the Operational Enviromment and lhe Suppont Infrasiructure.

The Operational Enviromment covers those faclors which are built into the system and are not easily changed. that is they have to be accepted and worked with. They include the political and economic situation at both the regional and national lcvel. the busincss and skill base available, and IJe legal and taxilion cuvironments. They also include the market the new cincrprise is trying to enter and the alliludes of the communily. of the university and of the banks to entreprencurial iniliatives.

The Support Infiast ructure refers to llose elements whicli can be put in place in a region as part of an cconomic 
development plan. Among the most important elements are the physical support infrastruclure, which includes business incubators and science parks, and the financial support infrastructure, which covers the provision of seed capital and venture capital .

Whilst this paper deals specifically with the support to the enterprise process provided by incubators and science parks it is important to recognise that they are only part. albeit an important onc, of the support infrastructure and that the operational environment can often profoundly influence their success.

3.1 The Role of the Incubator and the Science Park.

Incubators and science parks can be static places providing an accommodation facility and nothing more, that is they can be like hotels with little interaction between management or tenants. This very limited property role can work in some situations, for example il works in Cambridge. England where there is already a critical mass of technology-based businesses. However 10 limit incubators and science parks in this way is to miss a vital opportunity 10 contribute to the economic development of the region and to bring real benefits to the university sector. It is also likely that they will not achieve the results expected in terms of tenants, job creation or rental incollie.

The role of the incubator and science park is best understood as support facilities within the Suppont Infrastructure. The following lable relates the support facility to the stages of new enterprise gencration process and the mechanisms involved.

\begin{tabular}{|c|c|c|}
\hline Process & Mechanism & Support \\
\hline $\begin{array}{l}\text { Rescarch \& } \\
\text { Development }\end{array}$ & $\begin{array}{l}\text { R\&D Programmes with at } \\
\text { Commercial Focus }\end{array}$ & $\begin{array}{l}\text { University or other } \\
\text { Rescarch }\end{array}$ \\
\hline Embryo & $\begin{array}{lc}\text { Technology } & \text { Transfer } \\
\text { Programmes } & \text { Enterprise } \\
\text { Gencration } & \text { Programmes }\end{array}$ & $\begin{array}{l}\text { Entreprencur Sehool } \\
\text { Busincss Centre }\end{array}$ \\
\hline Nurture Stage & $\begin{array}{lr}\text { Enterprise } & \text { Support } \\
\text { Progranmes } & \text { including } \\
\text { Mentoring } & \end{array}$ & Incubator \\
\hline Fledgling & $\begin{array}{l}\text { Mentoring with Specialist } \\
\text { Programmes cg } \\
\text { Marketing }\end{array}$ & $\begin{array}{lc}\text { Enterprise } & \text { Centre or } \\
\text { Innovation } & \text { Centre }\end{array}$ \\
\hline Maluring & $\begin{array}{l}\text { Specialist Programmes eg } \\
\text { Exporting }\end{array}$ & Science \\
\hline Business & $\begin{array}{l}\text { Gencral } \quad \text { Consultancy } \\
\text { Support }\end{array}$ & Science Park or other \\
\hline
\end{tabular}


The first point from the above tabulation is that the incubator and the science park are esscutial support facilities in the enterprise generation and growth process. They bridge the critical gap belween start of the enterprise and its place in the business community. For technology-based companies this is a particularly critical gap because their founders often lave limited business experience and the step by step learning approach to growing a business which incubators, innovation centres and science parks make possible are invaluable.

The second point to note from this tabulation is that for the process to pass smoothly from one stage to another the mechanisms and their support facilities have to be in piace. Thus even if a business incubator and science park are in place there will be a problem of linking with the university activity if the embryo stage of the process is not addressed in some way. It is for this reason that some universities are considering entrepreneur schools as feeders to their business incubator.

The third point is that the tabulation makes a distinction between an incubator and an cnterprise centre or innovation centre. Although this distinction is not generally made I think it is extremely important because it focuses attention of the role of incubator. If the incubator is to support enterprises at the Nurture Stage then programmes which provide direct support and help are required. On the other hand if it is for enterprises at the Fledgling Slage then whilst some form of mentoring may be continued the enterprises IIIust learn to operate on their own.

The St. Jolnn's College Innovation Centre, Cambridge in which I was involved was for Fledgling Stage enterprises and although we did make available advice and training sessions they were not compulsory.

Many centres which I have seen are a combination of incubator and innovation centre in that they serve both Nurture and Fledging Stage enterprises. This is fine in many ways because the shared services and the entrepreneur community which develops are a common feanure. The danger is that if this distinction is not made in concept terms and understood by the enterprises then they will continue receiving support when they should have reached the stage of doing things themselves. This can easily develop into dependency situation in which the enterprise never learns to stand on its own feet and will fail as soon as it leaves the support environment of the incubator.

A final point to note is that as long as the sequence is maintained any of the stages can be linked together. Within a university setting for example research teams can link with the entrepreneur school and connect into an incubator. Proximity at these early stages is important and there is a definite advantage in having these activities all on campus. An innovation centre is best located within a science park complex and whilst it would be advantageous to have these facilities 


\section{PRODUÇÃO}

close to the university it is not essential. At Oxford and Cambridge for example the innovation centre and science park complexes are about $6 \mathrm{~km}$. from the university campus.

Another possible linkage is to combine a business centre and an incubator in the same building. This works well in a nonmiversity selling where the business centre rums programmes for the general public and the resulting businesses are housed in the incubator with support immodiately to land.

\subsection{Making the Incubator Work}

In order for an incubator or inmovation centre to work well it has to :

- Have the right enterprises

- Have the right mamagement team

- Be a community of ent repreneurs

- Be operationally efficient

Having the right enterprises means that those in the incubator are all at a similar stage of growth with the same entrepreneurial enthusiasms. It is also important that the incubator is full and that there are not cmpty units. These requircments relate directly to whether there is a feeder mechanism for the incubator such as an entrepreneur school and on the selection procedures used for incubator tenants.

In a recent incubator proposal it was specified that the tenant companies must :

l. be at the embryo, murture or fledgling stage of their growth

2. understand the incubator concepl

3. be known and recommended by at least one nember of the selection panel
4. be product-based companies rather than service-based

5 . be in the healthcare and hightechnology sectors

6 . not be warehousing and similar trading-type businesses

Of these the first 3 and the last were mandatory: Criteria 4 and 5 could be relaxed in order to fill the mits as quickly as possible. Once the incubator was full the criteria would be applied more rigorously.

It should be noted that there is no reference to business plans or to a panel of experts to select the best enterprises. This is because experience shows that there is little value in applying such controls. It is far better to fill the incubator and then be strict about making enterprises leave if they do not make progress or cannol pay the rent.

Having the right management team is about ruming the incubator in a user friendly way with a management team that can provide 'tender loving care' to the tenants without indulging them or being loo paternal.

The most critical appointment is that of the Centre Director who must have entrepreneurial, leadership and management skills with some degree of business experience. One of the weaknesses which I found in Latin America among the university-based incubators was that the Centre Directors were not involved in the local business community and so were unable to provide the bridge 
into that community required by their tenant companies.

Being a community of entreprencurs is the most important thing in getling the incubator to work. Although the management of the incubator sets the tone the building and its facilities play a vital role in stimulating a community of coltreprencurs.

One of the surprises at the St. John's Innovation Centre was the importance that the coffec shop played in getling people to know eacl other and in spreading an entrepreneurial enthusiasm about the place. Visitors often commented to the about the 'burt' and cxcitcment that they could fecl in the building.

The coffec shop had a business role as well as a social one and I know of al least one product that resulted when two people from different companies met in the colfee shop.

Being operationally efficient may be self-evident but start-up enterprises which are under pressure can be very demanding and it is important to be able to respond quickly and positively. Time delays and unnecessary paper work should be avoided and things like rental agreements should be made as simple as possible. Most incubators operate an "easy-in casy-out" rental policy but care must be taken to handle this efliciently and fairly.

Operational procedures should recognise the needs of the tenants. For. cxample the delivery of mail should be set up so that tenant companies can pick up their mail at any lime and even outside office hours.

\subsection{Malking the Science Park Work}

I have al ready commented that the UK Science Park Association's definition refers to a science park as a property-based initiative. The definition goes on to say that it is an initiative which:

o has formal and operational links with a university or higher education institution or major centre of research

o is designed to encourage the formation and growth of knowledgc-based businesses and ollher organisations normally resident on the site

o has a management function which is actively engaged in the transfer of technology and business skills 10 the organisations on the site.

This definition describes a 'dynamic' science park with a strong interaction between the university and the park. It sees the park as a velhicle for the generation and growth of new enterprises. In order to achieve this it is vitally important that right from the start the project is concept-driven and not properly-driven.

The EC SPRINT Feasibility Study for the Dublin Science Park completed in 1993 commented that 'A science park is primarily a concept or process and only secondarily a property will land and buildings. Through its linkages to the universities and its special-purpose facilities, it 
provides the continuity for research 10 move to the incubator stage, to product imnovation. to prololype production, to full manufaclure."

To bring concepts to reality they have to be cxpressed as models and made langible. A number of models are available which link with the science park concept and these need to be discussed by the sponsoring group to identify the onc which is the most appropriate in its particular situation.

A model which I have found useful is based on a set of three concentric circles as follows :

- Centre Circle - this comprises the incubator and innovation centre which gencratc and support enterprises through their nurture and fledgling stages.

- Middle Circle - this includes a range of buildings for enterprises which require their own front door and reception. These enterprises will be those that have graduated from the innovation centre and are at their maturing slage. There will also be small and medium-sized enterprises who have chosen to locate on the science park. These facilities may physically occupy the largest area on the park.

- Outer Circle - this covers the research and development activities of the instilutional and corporate sector.

In this model the concentric circles are sel within a background of the local university and business cnvironment. This background can be a source of technology'
Iransfer and trade for all the activities on the park but specifically it generates some of the new enterprises growing in the Centre Circle. For cxample spin-offs from the university.

Across the three concentric circle there is a constant transfer of people and ideas and a significant amount of trading takes place within the park itself. Thus a stantup enterprise in the incubator may have a development contract with one of the larger R\&D units in lic Outer Circle.

The best cxample of this model I have seen is the Oulu Technology Park in Northern Finland. The Centre Circle corresponds to their $2,000 \mathrm{sq} . \mathrm{m}$. Innovation Centre housing about 30 enterprises. The Middle Circle corresponds to a series of 14 buildings of $1,000 \mathrm{sq} . \mathrm{ml}$. cach of which is able to provide betwecen 3 to 5 enterprises with their own froml door. The Outer Circle is made up of 3 major laboratories. The universily and business background is strong in the areal and there are good links into the university.

One way to encourage the universily links is to have some university research groups actually based on the park. Another is to have joint development projects between the university and companies on the park. For cxample Trinily College. Cambridge has a scheme in which they pay $50 \%$ of the salary of a person employed in a company on the Cambridge Science Park 
so that that person call spend half their time working in a mniversity laboratory.

\section{An Essential Opportunity}

The generation and growth of new enterprises is an important activity for any region. It has the attraction that it creates businesses indigenous to the area and helps to build confidence in the community. In the past economic development policy has often been based upon attracting major intcrnational companies into a region. Although this 'inward investment' strategy can create jobs quickly experience has shown that they call disappear just as quickly. This experience has resulted in a new interest in the generation and support of indigenous businesses and an acceptance that although the jobs may take longer to create they are more likely to be sustainable in the longer term.

In this paper I have argued that incubators and scicnce parks are an essential part of the process of new enterprise generation. This view is endorsed by a recent UK Government report on Business Incubators which concluded that :

- Business incubators do help startup and businesses with high growth potential to succeed.

- Business incubators are an effective way of helping technology transfer. developing innovation and generating local jobs and cconomic development.
Whilst the importance of incubators and science parks may now be recognised they are not easy to implement successfully. Two critical success factors can be identified. Firstly the sponsors must all fully support the project and agree on its objectives. A typical point of conflict is between the short-term commercial requirements of the project and the original concept which generally has a long term focus. There are also difficullies when sponsors have their own agenda or when key players are replaced by others who are less commitled.

The second factor is the operational team and in particular its leader. In order to succeed such projects need an Operational Project Champion. This calls for a combination of entreprencurial and mantagement skills which is not easily found in one individual.

Studies in the USA with similar projects over a six year period bring these two points togelher in their conclusion that successful centres are built primarily upon strong leadership - both internal to the centre and cxternal from the agency direcling the effort'.

Despite these difficulties incubators and scicnce parks can be cxtremcly successful in terms of new enterprise gencration and growth. For cxample the UK Government report on Business lncubators gives the lollowing figures for the St. Joln's Innovation Park opened in 1987. "Al the end of 1994 the Park was occupied by 67 companies almost all less 


\section{PRODUÇÃO}

than five years old. Over 1000 people are employed on the site and the turnover of client businesses is in excess of $\$ 75$ million per year. The success rate for such companies is over 88 per cent."

When I began the St. John's project in 1984 I had very little experience of business incubators or of science parks. As commented earlier a 'new enterprise' project with my industrial engineering students revealed potential entrepreneurs in the group and so I sought ways in which they could be provided with help and support if they went alicad and set up their own enterprise. In the carly 1980s I visited Professor Wayne Brown of the Ulah
Innovation Centre in Salt Lake City and became convinced that a business incubator would solve this problem. From these small beginnings the St. John's Innovation Park was born.

The lesson here is that we do not need to be experts or know all the answers but we do need a concept and then the will and the opportunity to actually make it happen. This I believe is a challenge that the university sector in particular must respond to as it sccks ways to support its research programmes and its graduates find it increasingly difficult to get jobs in the large companics. 